DOI: http://doi.org/10.31617/k.knute.2019-03-19.59

\title{
СУТНІСТЬ ТА СПЕЦИФІКА РЕКЛАМУВАННЯ ПОСЛУГ ГОТЕЛЬНО-РЕСТОРАННОЇ СФЕРИ
}

\author{
Парубок Н. В. \\ к.е.н., старший викладач \\ кафедра туризму та готельно-ресторанної справи \\ Уманський національний університет садівництва, Украйна
}

Ключові слова: рекламна діяльність, послуги, просування, готельноресторанний бізнес.

Keywords: advertising activity, services, promotion, hotel and restaurant business.

У силу своєї природи послуги не мають гарантованих стандартів якості. Послугам властивий високий ступінь невизначеності або мінливості. Ця обставина ставить споживача послуг у невигідне положення, тому що результат послуги, іiі корисний ефект він зможе оцінити лише після іiї надання; а виробникам у цих умовах складно здійснювати просування послуг.

Саме в силу своєї невизначеності або мінливості сфера послуг потребує державного регулювання більшою мірою, ніж ринки інших товарів. Найчастіше державне втручання у функціонування ринку послуг викликається не тільки економічними, але й політичними та соціальними причинами [2, с. 98].

У зв'язку зі специфікою сфери послуг до комплексу маркетингу послуг зараховують ще три складові, що формують стандарти обслуговування фірми:

- персонал як головний ресурс зростання у сфері послуг(його кваліфікація, професіоналізм);

- процес здійснення продажу послуг (характер і якість обслуговування, час, що клієнт витрачає на придбання послуги);

- оточення (зокрема інтер'єр, що також відіграє певну роль у залученні клієнтів).

Отже, рекламування послуг з практичної точки зору - це комплекс дій, котрі виконує продавець послуг для того, щоб пояснити клієнтам, що він для них робить, як він це робить, і довести вигідність придбання тієї або іншої послуги. Остання обставина особливо важлива, тому що продавець з'являсться на ринку не 3 реальним товаром, а з обіцянками зробити щось, що має для клієнта особливу цінність. Тому виробники послуг повинні оцінити свій товар ніби 
«очима покупців». Адже, відповідно до концепції маркетингу, споживачі купують не товар, вони одержують задоволення від користування цим товаром [3, с. 184].

Аналіз концепцій просування послуг дозволяє зробити висновок, що всі вони мають схожі структурні і концептуальні елементи:

1. Усі моделі базуються на специфіці послуги як товару.

2. Усі моделі вказують на необхідність уваги до таких стратегічних факторів маркетингу послуг, як персонал, процес обслуговування і матеріальний аргумент обслуговування.

3. Більшість концепцій визнає необхідність використання додаткових стратегій для управління маркетингом послуг. До таких додаткових стратегій належать внутрішній маркетинг та інтерактивний маркетинг.

Зазначені особливості сфери послуг зумовлюють наявність специфічних характерних рис самих послуг. Найважливішою характерною рисою послуг $\epsilon$ те, що в структурі товару-послуги домінують невідчутні якості. Однак багато ринкових пропозицій містять у собі як відчутні, так і невідчутні аспекти. Наприклад, внаслідок проведення маркетингових досліджень з'являється звіт (матеріальний товар), в якому зображено результати цілого ряду послуг (спілкування із споживачем, розробка стратегії досліджень, опитування респондентів, аналіз результатів). Усе це свідчить про те, що розбіжність між пропозицією матеріального товару і товару-послуги належить розглядати як відносне, а не абсолютне явище.

Невідчутність послуг означає, що їх неможливо продемонструвати, побачити, спробувати, почути тощо до моменту їх придбання. Усе це створює проблеми як у покупців, так і у продавців послуг. Покупцю складно розібратися й оцінити, що ж він купує до придбання послуги, а іноді навіть після іiі одержання. Покупець повинен або вірити продавцю послуг на слово, або довіритися думці тих людей, що вже отримували послуги в даного продавця. Тому з боку споживачів послуг дуже важливу роль відіграє фактор довіри до продавця, що необхідно враховувати в маркетингу послуг [1, с. 8].

У той же час невідчутність послуг створює додаткові труднощі і для виробників послуг. Вони не можуть продемонструвати свій товар i, отже, їм складно пояснити клієнтам, за що ж вони сплачують гроші. Це ускладнює створення рекламного продукту, просування і збут послуг, утруднює процес ціноутворення [4, с. 45]. Виробники можуть лише описати ті вигоди і той ефект, що має одержати покупець послуг після їх придбання, що також потребує довіри з його боку. Для зміцнення довіри споживачів виробники послуг можуть вжити ряд конкретних заходів. 
По-перше, вони мають підвищити відчутність своїх послуг. Наприклад, фахівець 3 інтер'єру або дизайнер можуть надати клієнтам макети, ескізи майбутнього оформлення офісу або готелю.

По-друге, продавець послуг може не просто описати свою послугу, а підкреслити користь або вигоду, що одержить покупець, скориставшись нею.

По-третє, для підвищення ступеня відчутності послуг виробнику варто розробити й активно пропагувати свій фірмовий знак, до реклами варто залучити людей, що користуються популярністю і довірою в потенційних споживачів послуг. Дуже корисно 3 цією метою використовувати брошури, буклети, інші матеріальні носії інформації, що допомагають зрозуміти й оцінити послуги, що надаються.

Невіддільність від джерела означає, що послуги здебільшого виробляються i споживаються одночасно. Отже, покупець ніби включається в процес виробництва послуги і знаходиться у безпосередньому контакті з виробником послуг. Це призводить до того, що при наданні багатьох видів послуг визначальним мотивом вибору того або іншого виробника є не стільки «користь», результат якоїсь послуги, скільки процес ії одержання. Те, як працівники готелів і ресторанів поведуться зі своїми відвідувачами, значною мірою визначається можливість повторного до них звернення. Тому в маркетингу послуг велику роль відіграє кваліфікація, добір і навчання персоналу фірми.

\section{Список використаних джерел}

1. Кожухівська Р. Б. Інвестиційна привабливість рекламного ринку України на основі Інтернет-комунікацій / Р. Б. Кожухівська // Інвестиції: практика та досвід. - 2012. - № 5. - С. 7-11. - Режим доступу : http://nbuv.gov.ua/UJRN/ipd_2012_5_4

2. Лидовская О. Оценка эффективности маркетинга и рекламы. Готовые маркетинговые решения / О. Лидовская. - Питер, 2010. $144 \mathrm{c}$.

3. Лук'янець Т. I. Рекламний менеджмент : навч.-метод. посіб. для самост. вивч. дисц. / Т. І. Лук'янець. - Київ : КНЕУ, 2002. - 200 с.

4. Страшинська Л. В. Маркетинг готельного і ресторанного господарства : конспект лекцій з дисципліни «Маркетинг готельного і ресторанного господарства» для студ. спец. 6.140101 «Готельноресторанна справа» / Л. В. Страшинська. - Київ : НУХТ, 2011. 89 c. 